\title{
CHEMNITZ'S EUCHARISTIC CHRISTOLOGY AS AN IMPULSE FOR ECUMENICAL DIALOGUE BETWEEN EAST AND WEST
}

\author{
Michal Valčo
}

DOI: 10.17846/CL.2017.10.2.141-150

\begin{abstract}
VALČO, Michal. Chemnitz's Eucharistic Christology as an Impulse for Ecumenical Dialogue between East and West. Martin Chemnitz, an important second-generation, reformation theologian, combined Luther's theological insights and exegetical skills with Melanchthon's logical methods of argumentation in his patient search for ecumenical concord. His major theological contribution was his development of an historical method, which he used in his polemics, thus delineating the roots and context of legitimate 'Gospel theology.' This method is comprised of: (1) Biblical exegesis, (2) thorough research of the church's tradition to guide exegesis (keeping the Scriptures as the ultimate authority in case of discrepancies or conflicting views), (3) dogmatic construction, and (4) apologetics. Chemnitz used this method in developing and using his Christological teaching in several key doctrines, including his doctrine of the Eucharist. Relying on what he called a "catholic consensus of the fathers," Chemnitz extensively used the witness of the ancient fathers of the church - including Eastern church fathers, which distinguished him from other Protestant theologians of his time - as a legitimate source of Christology, as well as other important topics. This "catholic consensus" should be perceived as a further development of the tradition of biblical interpretation within the living organism - the ecumenical Body of Christ. The witness of biblical interpretation of the Christological passages as found in Cyril of Alexandria, John of Damascus, or Basil the Great is welded together with the words of institution, as found in the Gospels and in Paul, the apostle. Chemnitz's approach carries a relevant ecumenical potential for the dialogue between Eastern and Western branches of Christianity.
\end{abstract}

Keywords: Martin Chemnitz, Christology, Eucharist, perichoresis, communicatio idiomatum, Biblical Hermeneutic, words of Institution, Tradition

Abstrakt: VALČO, Michal. Chemnitzova eucharistická kristológia ako impulz pre ekumenický dialóg medzi východom a západom. Martin Chemnitz, dôležitý predstavitel druhej generácie nemeckej reformácie, spojil Lutherove teologické myšlienky a exegetické schopnosti s Melanchthonovou logickou metódou argumentácie a využil ich v trpezlivom hladaní svornosti medzi evanjelickými protestantmi. Jeho najväčším teologickým príspevkom bolo vytvorenie historickej metódy, ktorú používal v polemike, čím sa pokúsil načrtnút korene a kontext legitímnej luteránskej teológie: (1) biblická exegéza; (2) kritické spracovanie cirkevnej tradície s Písmom ako najvyššou autoritou; (3) na to nadväzovala formulácia dogmatických téz a (4) apologetická argumentácia. Chemnitz túto metódu používal pri rozvoji a aplikácii svojho kristologického učenia $\mathrm{v}$ rámci klúčových teologických tém, vrátane problematiky eucharistie (večere Pánovej). V otázke kristológie, ako aj pri iných dôležitých učeniach, sa spoliehal na takzvaný „katolícky konsenzus otcov“ - vrátane otcov Východnej cirkvi, čím sa výrazne líšil od iných, súdobých protestantských teológov. Tento „katolícky konsenzus“ však nebol ničím iným (podla Chemnitza), ako d’alším rozvinutím tradície biblickej interpretácie v rámci živého organizmu - ekumenického Tela Kristovho. Svedectvo biblickej interpretácie kristologických textov, nájdených u Cyrila Alexandrijské- 
ho, Jána Damascénskeho, alebo Bazila Velkého, je prepojené so slovami ustanovenia, ako ich nachádzame v evanjeliách a $\mathrm{u}$ apoštola Pavla. Chemnitzov prístup so sebou prináša dôležitý ekumenický potenciál pre dialóg medzi východnou a západnou vetvou krestanstva.

Klúčové slová: Martin Chemnitz, kristológia, eucharistia, perichoréza, communicatio idiomatum, biblická hermeneutika, tradícia

\section{A Short Biographical Introduction}

Martin Chemnitz was an important second-generation, reformation theologian. His theological significance was coupled with his significance as a pastor and church administrator (Kolb 1996, 309-310). Nevertheless, he remains underappreciated today, especially in terms of his ecumenical potential relevant to contemporary debates on Christology, sacramentology, liturgy, and hermeneutics. To gain a clearer understanding of Chemnitz's Christology and his theology of the Eucharist, it is important to consider the formative events of his life, his ecclesiastical-political struggles, as well as his pastoral approach to matters, which he considered most important.

The most important influence on Chemnitz's youth and adolescence were his parents and the teachers of the schools he attended, including the theological faculty at Wittenberg, where he studied under the tutelage of Phillip Melanchthon (Graebner 1899). Melanchthon greatly influenced Chemnitz, although the latter later gravitated to the gnezio-Lutheran party. Until the end of his life, Chemnitz honored and respected his great teacher. From a librarian (in the Koenigsberg Schlossbibliothek of Duke Albrecht) and a court astrologer developed a theologian, interested both in patristic thought and in faithfully preserving and applying Luther's theology. Interestingly enough, his study zeal was motivated not only by his intellectual curiosity, but also by his own personal, devotional needs (Graebner 1899, 482). The heart of a shepherd and the mind of a theologian worked together to motivate and form the work of Chemnitz as pastor and superintendent.

Other important formative influences were the theological controversies with Andreas Osiander, Albert Hardenberg, Matthias Flacius, and Payva d'Andrada, in which Chemnitz became involved during his career. In the heat of these debates, the character and the methodology of his theological mind were forged. Well prepared, both academically (studies at Koenigsberg, Wittenberg and Rostock) and personally (shaped by friends and theological sparing partners), Chemnitz began his ecclesiastical service as a co-adjutor to his close friend, superintendent Joachim Moerlin, whom he later succeeded as superintendent of the church in Braunschweig (Brunswick). He was uncompromising in his demand that the teaching of the evangelicals be orthodox (i.e. faithful to the gospel). He likewise was firm on questions of church discipline (Graebner 1899, 485). Yet his moderation, humility, and considerable patience and persistence enabled him to quench many fiery disputes and reconcile apparently irreconcilable theological opponents. His gift of patient diplomacy, yet without sacrificing the common search for truth, was best evident during efforts to complete the Formula of Concord (1577), a reconciling document of quarrelling Lutheran factions that had delineated theological orthodoxy for future generations (Jungkuntz 1977, 61-68). 


\section{Chemnitz's New (Ecumenical) Historical Method}

In his patient search for concord, Chemnitz combined Luther's theological insights and exegetical skills with Melanchthon's logical methods of argumentation. His major theological contribution, besides his important theological treatises, such as Loci Theologici (1591), De duabus naturis (1578), Examen Concilii Tridentini (1566-73) etc., was his development of an historical method, which he used in his polemics, thus delineating the roots and context of legitimate 'Gospel theology.' This method is comprised of: (1) Biblical exegesis, (2) thorough research of the church's tradition to guide exegesis (keeping the Scriptures as the ultimate authority in case of discrepancies or conflicting views), ${ }^{1}$ (3) dogmatic construction, and (4) apologetics.

Chemnitz used this method for developing his Christological understanding which he then implemented in several key doctrines, including his doctrine of the Eucharist (which he would refer to as "Lord's Supper"). The mature summary of his eucharistic teaching was finally published in 1570 under the title: Fundamenta Sanae Doctrinae De Vera Et Substantiali Praesentia, Exhibitione Et Sumptione Corporis Et Sanguinis Domini in Coena, later known by its shorter name De coena Domini (Chemnitz 1570). The book builds on the material from four earlier, shorter works on the subject by Chemnitz: Anatome Propositionum Alberti Hardenbergii De Coena Domini (1561a); Die Reine Gesunde Lehre Von Der Wahren Gegenwertigkeit Des Leibs Und Bluts Christi in Seinem Abendmal (1561b); Leuterung Der Proposition Oder Schlusreden Alberti Hardenbergers Von Dem Abendmal Des Herrn (1561c); and Repetitio Sanae Doctrinae De Vera Praesentia Corporis Et Sanguinis Domini in Coena (1561d).

To be sure, Chemnitz relied first and foremost on his meticulous biblical exegesis to interpret the relevant texts pertaining to Christology and the sacraments. Though an excellent systematic theologian, he did not deduce the basic Christological teachings, such as the real presence of Christ's body and blood under the elements of the bread and wine in the Eucharist, directly from Christology. Chemnitz rather used the Christological teaching of the ecumenical Church merely as a necessary metaphysical and intellectual framework for a thorough interpretation of relevant biblical texts. Each theological topic has its own "relevant texts" which Chemnitz called sedes doctrinae (the roots and seeds of the doctrine). (Valčo 2010) With regard to the sacraments, these can be found in the words of institution in the Gospel of Matthew, Mark and Luke. These words are foundational because they belong to Christ himself, constituting His last will and testament valid for the whole ecumenical church of all ages. (Chemnitz 1999, 121; cf. Valčo 2007, 5) He makes this clear very early on in his De Coena Domini: “Therefore the best and safest rule is to lead the minds of people to the very words of the last will and testament of the Son of God and to a consideration of their importance... For this reason we should pay closer attention to godly teachers, so that by means of their earnest warnings, based on the true foundation, people can turn their attention away from all these disputes and cling to the very words of the covenant of the Son of God and to respect them piously and sincerely in order not to want to know more or to be able to listen to something else in this argument than to the holy words of the Son of God, our Savior, which he commanded us in the form of his last will or testament in the night when he was betrayed." (Chemnitz 1979, 20) One must, therefore, build one's theological insight on "a comparison, congruence, and mutual explanation of those four texts of the Scripture that directly deal with the institution of the Eucharist: Matthew 26, Mark 14, Luke 22, and First Corinthians 11" (Chemnitz 1979, 91), while adhering to the literal meaning of the words unless the context clearly shows a completely opposite meaning. Following a rigorous exegetical analysis of all four foundational texts, Chemnitz argues that none of them exhibits any sign of allegorical or metaphorical meaning. The words of the institution have

"[T]he decrees of the councils be examined according to the norm of Holy Scripture." (Chemnitz 1971a, 3). 
such a unique character that they "require a high degree of historical veracity" (Volk 1987, 188). In addition, it would be impossible to establish a conclusive and reliable meaning from Christ's words of institution, unless one took them at face value, i.e. in their literal sense. ${ }^{2}$

\section{Chemnitz's Use of the Tradition}

Besides the norma normans (i.e. Scriptures), ${ }^{3}$ Chemnitz extensively uses the witness of the ancient fathers of the church - including Eastern church fathers, which distinguished him from other Protestant theologians of his time - as a legitimate source of Christology. A fitting example of this is Chemnitz's use of tradition in his De Coena Domini (1570): while Luther is cited only about two dozen times, John of Damascus is cited more than 120 times! Along with John of Damascus, numerous fathers, both from East and West, are cited: Ambrosius, Athanasius, Augustine, Basil the Great, Bernard of Clairvaux, Boethius, John Chrysostom, Cyprian, Cyril of Alexandria, Eucherius, Gregor of Nazianz, Gregor of Nyssa, Hillarius, Ignatius of Antiochia, Irenaeus (12 times!), Justin Martyr, Origen of Alexandria etc. The same is true in Chemnitz's major Christological book, De duabus naturis in Christo (1578), as well as in the so-called Catalogus Testimoniorum (1580), ${ }^{4}$ a concise overview of the testimonies of the church fathers attached to the Formula of Concord (1577) (Chemnitz 1997, 1105-1149).

Chemnitz elaborates on Luther's own Christological insight, as presented in his Confession concerning Christ's Supper (1528): "wherever you place God for me, ${ }^{5}$ you must also place the humanity for me. They simply will not let themselves be separated and divided from each other. He has become one person and does not separate the humanity from himself" (Luther 1999, 219). Agreeing with Luther and reiterating his ideas, however, did not seem to be enough for Chemnitz. He turned to the Eastern fathers and added some distinctly Eastern flavor to Lutheran (Western) Christological teaching, which subsequently ended up being codified in Lutheran churches via Article VIII (On Christology) of the Formula of Concord, one of the five key confessional writings of the Lutherans (ELSM 1921, 1014-1047). As Watson rightly points out, following Pannenberg's observation in his book on Christology (Pannenberg 1977, 302), Eastern emphasis can most clearly be perceived in "the Lutheran Christological understanding of the communication of divine majesty to Christ's humanity (the unilateral movement from Christ's divinity to his humanity)," which is evidently "dependent on John of Damascus." (Watson 1994, 78) Chemnitz argues that Christ's person is indivisible based on the unio hypostatica, which must be affirmed unless one wishes to stray to Nestorius' position. Other Protestant theologians of that time would not have hesitated to go thus far. But we find something else at the core of Chemnitz's Christology, an idea from John of Damascus and others in the East - the teaching of perichoresis. Due to perichoresis

2 Martin Luther argues similarly in his Confession concerning Christ's Supper (1528, 305n); Chemnitz notices that the same reason is given by Augustine in his Contra litteras Petiliani $(1865,43)$ as cited by Chemnitz $(1979,81)$ and we can also observe a parallel reasoning in Irenaeus' Adversus haereses (1857, 802, Book II, 46)

3 Lutheran reformers distinguished between the so-called "norma normans" - the Biblical Scriptures as the primary, normative source of revelation, and the so-called "norma normata" - the ecclesial tradition of summarization and/or interpretation of the scriptural message, subjected to the authority of the norma normans.

4 It is interesting to note here that out of 21 cited fathers of the church, 16 are from the East! (Cf.: Watson 1994, 85).

5 This is Luther's important emphasis of "God for me" - Deus pro me, which Luther related to the person and work of Christ in his both natures. 
of the divine and human natures in Christ's single hypostasis, the idiomata of Christ's divine nature must be ascribed to his human nature (based on the teaching of "communicatio idiomatum"), too, which brings Chemnitz to the teaching of ubiquity (here he follows Luther's lead) of Christ with both his natures (Chemnitz 1561a; cf. Mahlmann 1969, 54-56). Within the hypostatic union (the enhypostasis of Logos), there is a unilateral communication of majesty from the divine to human nature in the person of Christ (Mahlmann 1969, 217). Chemnitz calls this "the third genus" - genus maiestaticum (Chemnitz 1971b, 241ff). Divine glory and majesty is thus imparted to Christ's human nature, causing Christ's flesh to be "deified" but not in the sense of transforming it into divine nature. While remaining fully human, Christ's body is so fully penetrated by divine glory that it becomes life-giving (Chemnitz 1591, 88f). For this, Chemnitz finds ample evidence in Athanasius, Basil the Great and, above all, John of Damascus: "Again, please not the expression 'the flesh of Christ vivifies,' but not of itself but by and through something else, and it performs its divine works in a way which we shall describe. 'For heated iron also gives heat, not because it possesses of its own nature the power to give off heat but because it has acquired it as a gift and possesses and obtains this power from the union of the iron with the fire.' (Damascenus 1864, 1069) Thus the flesh of the Lord is mortal of itself but life-giving because of its personal union with the Logos." (Chemnitz 1971b, 380). Other, typically eastern Christological terms are abundantly present in Chemnitz's De duabus naturis in Christo, such as enhypostaton, physis, ousia, hyperfysika, parafysika, koinonia, homoousios etc. (Chemnitz 1971b, 29-36) - and, again, most of them are presented under the heavy influence of the Damascenus. ${ }^{6}$ Also interesting is the fact that unlike Luther (for which he reaped a good dose of criticism), Chemnitz amply and "favorably cites the decrees of the fifth, sixth, and seventh ecumenical councils." (Watson 1994, 79)

Chemnitz relied on what he called a "catholic consensus of the fathers" (Chemnitz 1971a, 78) with regard to the basic teachings of the gospel. This "catholic consensus," however, was but a further development of the tradition of biblical interpretation (Olsen 2000, 324) within the living organism - the ecumenical Body of Christ (Chemnitz 1971a, 63-64). Chemnitz's use of such "traditional consensus," however, was carefully qualified, based on his differentiation of various kinds of traditions. "By emphasizing the fact that there were various types of traditions in the church and not simply one, he dealt a blow to the Roman posturing that Rome alone possessed true apostolic tradition." (Stewart 2015, 56) As Stewart further argues, analyzing Chemnitz's approach to ecclesiastical tradition, "the reality was that the patristic, medieval and late medieval catholic traditions were multiform, therefore Scripture alone had to be the final arbiter between which of the traditions was the most reliable and apostolic." (Stewart 2015, 56) Nevertheless, against the danger of arbitrary, private judgments, Chemnitz establishes the following rule: "We also gratefully and reverently use the labors of the fathers who by their commentaries have profitably clarified many passages of the Scripture. And we confess that we are greatly confirmed by the testimonies of the ancient church in the true and sound understanding of the Scripture. Nor do we approve of it if someone invents for himself a meaning which conflicts with all antiquity, and for which there are clearly no testimonies of the church." (Chemnitz 1971a, 63-64)

This principle of biblical interpretation (seen critically in the context of the consensus of the fathers) can be discovered in Chemnitz's works on the Eucharist, Christology as well as doctrine of justification by grace through faith. The witness of biblical interpretation of the Christological passages as found in Athanasius, Cyril of Alexandria, John of Damascus, or Basil the Great is

6 Though not blindly uncritical towards Damascenus, Chemnitz believes that "in regard to the doctrine of the Trinity and especially the doctrine of Christ, he cites correct statements from the outstanding doctors of the early church and the ecumenical councils, using almost the very words of the authors whom he quotes." (Chemnitz 1971b, 379) 
welded together with the words of institution, as found in the Gospels and in Paul, the apostle. This combined witness of Scriptures and tradition clearly shows, according to Chemnitz, that Christ's words of the institution (of the Eucharist) are meant to be taken literally and understood in their proper sense and context. Christology, though not a starting point in Chemnitz's exegesis of the sedes doctrinae of the doctrine of the Eucharist, has a very clear and definitive significance for this teaching. By means of a legitimate analogy between the hypostatic union of the two natures in Christ and union of Christ's body and blood with the elements of bread and wine in the Supper, Chemnitz demonstrates not only the possibility (or feasibility) but also the necessity of the sacramental union for human salvation. Christ's body given for us in His Supper is truly vivifying. Therefore, in addition to the common (Western) emphasis on the forgiveness of sins as the main benefit of holy communion, the Eastern emphasis on theosis - the sinner's inclusion in the fellowship of love of the Trinity via uniting with Christ in body and Spirit through the sacrament - could make its way into Western, Protestant theology. In addition, we may concur with Watson's observation that besides achieving a "greater sense of Lutheran Christological unity," Chemnitz's Christology helped "preserve Luther's Christological insights" (Watson 1994, 85), implied for example in his doctrine of ubiquity (cf.: Volk 1987; Mahlmann 1969; Congar 1966; Noth 1930, 22-25) 7 and continues to exert its ecumenical relevance in the dialogue between the Lutheran churches and the churches of the East (cf. Stewart 2015; Rusch 1987; Tsirpanlis 1982; Frank 1982).

\section{Conclusion}

Chemnitz's approach carries a relevant ecumenical potential for the dialogue between Eastern and Western branches of Christianity, beginning with theological hermeneutics (above all with respect to the relationship Scripture and tradition) and continuing on to Christology, Sacramentology, Christian liturgy and ethics. Chemnitz's biblical hermeneutics employed in key Christological and Eucharistic interpretations emphasizes the following four steps that might prove useful in contemporary ecumenical debates: (1) the need to determine in which passages metaphoric expressions (metaphors) are acceptable and in which they are not acceptable; (2) the need to be critically aware of the common experience of the human mind trying to avoid through metaphoric expressions such things that are talked about literally; (3) the importance to identify and pay attention to the analogies of interpretation of those texts which serve as a true basis for the given teaching/topic (dogma); (4) the need to hold on to the principle that no teaching can be based only on the basis of passages with a figurative, metaphoric or allegoric meaning.

His theological hermeneutics then places the act of biblical interpretation into a wider and more dynamic (organic) context of the living tradition in the worshipping and confessing visible church as the Spirit-guided Body of Christ, ecclesia militans. Here the common witness of the ecumenical church comes to bear upon one's individual act of interpretation. Knowing the biblical narrative of the triune gospel handed down in the creedal faith of the living Tradition, predisposes one to constructively embrace the dialectic of Scripture - Tradition. Creedal Christology (answering the question: who is Christ?) informs soteriology and soteriology together with Christology has direct implications for Chemnitz's Eucharistic theology and pastoral care.

The analogy between hypostatical union of the two natures in one person of Christ and sacramental union of Christ with the visible elements of the Eucharist has its theological

Noth is right to point out Melanchthon's departure from Luther's original Christological emphases, especially those related to the doctrine of Eucharist, while also claiming that Chemnitz in his struggle against crypto-Calvinism had remained more faithful to Luther's teaching. (Noth 1930, 25) 
consequences not only for the teachings related to sacramentology (such as transubstantiation, reservation or the real absence of Christ's body in the Supper) but also for other central doctrines of the Christian faith, such as the Lutheran teaching of simul iustus et peccator. Furthermore, Chemnitz's theological genius rests in his ability to engage in the so called "second order discourse", that is, being able to analyze the metaphysical pre-suppositions of his contemporaries. Where he falls short is the ability (or rather, inability) to reflect self-critically on his own presuppositions. Last but not least, Chemnitz's theological enquiry and active participation in theological disputes was always permeated by his pastoral concern for the church. Questions of Christology and sacramentology were thus intimately linked to an acute pastoral need to provide a viable consolation for anxious and terrified consciences.

\section{REFERENCES}

\section{Primary sources}

Augustine, St. 1865. Contra litteras Petiliani libri III. Migne, Jacques-Paul (ed.). Patrologiae cursus completus, series latina. Vol. 43. Paris, 245-390.

Damascenus. 1864. Expositio Accurata Fidei Orthodoxae [De Fide Orthodoxa]. In Migne, JacquesPaul (ed.). Patrologiae cursus completus, series graeca. Vol. 94 [online]. Documenta Omnia Catholica. Paris. http://www.documentacatholicaomnia.eu/25_20_25-_Rerum_Conspectus_ Pro_Auctoribus_Ordinatus.html.

ELSM. 1921. Evangelical Lutheran Synod of Missouri. Triglot Concordia: The Symbolical Books of the Ev. Lutheran Church. St. Louis.

Chemnitz, Martin. 1561a. Anatome Propositionum Alberti Hardenbergii De Coena Domini... Et: Declaratio Articule Decimi in Confessione Augustana De Coena Domini... (Ins Deutsche Gebracht Durch Johannes Zanger, Eisleben 1561). Eisleben.

Chemnitz, Martin. 1561b. Die Reine Gesunde Lehre Von Der Wahren Gegenwertigkeit Des Leibs Und Bluts Christi in Seinem Abendmal, Wie Dieselbe in Den Evangelischen Kirchen Der Augspurgischen Confession Verwandt Bissanher Gelehret Ist Und Noch Gelehret Wirdt, in Kurtze, Deutliche, Einfeltige Heuptstücke Im Latein Zusamengezogen Durch M. Martinum Kemnitz ... Jetzundt Aber Dem Einfeltigen Leser Zugut Ins Deutsch Verfertiget Durch Johannem Zanger. Lipsiae.

Chemnitz, Martin. 1561c. Leuterung Der Proposition Oder Schlusreden Alberti Hardenbergers Von Dem Abendmal Des Herrn, Welche Er Auff Dem Kreistag Zu Braunschweig Den Stenden Des Nidersechsischen Kreis Ubergeben Hat. Sampt Erklerung Des Zehenden Artickels Der Augspurgischen Confession, Wie Die Lere Vom Abendmal Des Herrn Bey Lutheri Zeit Und Leben Verstanden Sey Worden. Auch Von Den Propositionibus Oder Schlussreden Der Prediger Von Bremen Etc. Zuvor in Latein Gestellet Durch Herrn M. Martinum Kemnitz, Itzt Aber Ins Deutsche Gebracht Durch Johannem Zanger. Eisleben.

Chemnitz, Martin. 1561d. Repetitio Sanae Doctrinae De Vera Praesentia Corporis Et Sanguinis Domini in Coena. Additus Est: Tractatus Complectens Doctrinam De Communicatione Idiomatum. Lipsiae.

Chemnitz, Martin. 1566-73. Examen Decretorum Concilii Tridentini, in Quo Ex Sacrae Scripturae Norma, Collatis Etiam Orthodoxis Verae Et Purioris Antiquitatis Testimoniis Ostenditur, Qualia Sint Illa Decreta Et Quo Artificio Sint Composita... Volumes 1 - 4. Frankfurt. 
Chemnitz, Martin. 1570. Fundamenta Sanae Doctrinae De Vera Et Substantiali Praesentia, Exhibitione Et Sumptione Corporis Et Sanguinis Domini in Coena. Repetita a Martina Chemnitio. Jenae.

Chemnitz, Martin. 1577. Enchiridion, in Quo Praecipua Capita Coelestis Doctrinae Per Quaestiones Ex Verbo Dei Et Forma Sanorum Verborum in Ecclesiis Saxonicis Usitata Explicantur..., Nunc Vero Latine Conversum Per Iohannem Zangerum. Henricopoli. [originally published in a less developed form under: Die Fürnemsten Heuptstück Der Christlichen Lehre, Wie Darin Die Pastores Der Kirchen Im Fürstenthumb Braunschweig Etc. In Den Jerlichen Visitationibus Also Examiniret Und Befraget Werden, Das Sie Zugleich Darin Gründtlich Berichtet Und Unterweiset Werden, Wolfenbüttel, 1569].

Chemnitz, Martin. 1578. De Duabus Naturis in Christo, De Hypostatica Earum Vnione, De Communicatione Idiomatum, Et De Aliis Quaestionibus Inde Dependentibus. Libellus Ex Scripturae Sententiis, Et Ex Purioris Antiquitatis Testimoniis. Iam Denuo Recognitus Et Retextus Per Martinum Chemnicium D. Cum Praefatione D. Nicolai Selnecceri, Pastoris Lipsensis. Lipsiae.

Chemnitz, Martin. 1591. Loci Theologici Reverendi Et Clarissimi Viri D. Martini Chemnitii, Sacrae Theologiae Doctoris Atque Ecclesiae Brunsvicensis Quondam Superintendentis Fidelißimi, Quibus Et Loci Communes D. Phil. Melancthonis Perspicue Explicantur, Et Quasi Integrum Christianae Doctrinae Corpus, Ecclesia Dei Syncere Proponitur. Editi Nomine Haeredum Opera Et Studio Polycarpi Leiseri D., Successoris Ipsius. [Prima Pars]. Francoforti [Frankfurt].

Chemnitz, Martin. 1971a. Examination of the Council of Trent. Volume 1. Kramer, Fred (ed. et transl.). St. Louis.

Chemnitz, Martin. 1971b. The Two Natures in Christ. Trans. J.A.O. Preus. St. Louis.

Chemnitz, Martin. 1979. The Lord's Supper = De Coena Domini. Trans. J.A.O. Preus. St. Louis.

Chemnitz, Martin. 1997. Catalogus testimoniorum [German edition: Verzeichnüs der Zeugnissen] (1580). In Bente, Friedrich - Lutheran Church Missouri Synod. Concordia Triglotta - English : The Symbolic Books of the Evangelical Lutheran Church. Electronic edition. Milwaukee, 1105-1149.

Chemnitz, Martin. 1999. Ministry, Word, and Sacraments: an Enchiridion. Electronic edition. Poellot, Luther (ed. et transl.). St. Louis.

Irenaeus, St. 1857. Adversus haereses libri quinque. In Migne, Jacques-Paul (ed.). Patrologiae cursus completus, series graeca. Vol. 7. Paris, 431-1224.

\section{Secondary sources}

Congar, Yves. 1966. The Christology of Luther. In Loretz, Philip (ed. et transl.). Dialogue Betweeen Christians. Westminster, Maryland, 372-406.

Frank, G.L.C. 1982. A Lutheran Turned Eastward: The Use of the Greek Fathers in the Eucharistic Theology of Martin Chemnitz. In St Vladimir's Theological Quarterly 26/33, 155-171.

Graebner, August L. (transl.). 1899. An Autobiography of Martin Kemnitz [Vita Martini Chemnitii]. In Theological Quarterly III/4 (October 1899), 472-87.

Jungkuntz, Theodore R. 1977. Formulators of the Formula of Concord: Four Architects of Lutheran Unity. St. Louis.

Kolb, Robert. 1996. Martin Chemnitz. In Hillerbrand, Hans J. (ed.). The Oxford Encyclopedia of the Reformation. New York, 309-10.

Luther, Martin. 1999. Confession Concerning Christ's Supper. In Luther's Works [cit. LW], Vol. XXXVII. Philadelphia, 153-371. 
Mahlmann, Theodor. 1969. Das Neue Dogma Der Lutherischen Christologie; Problem Und Geschichte Seiner Begründung. Gütersloh.

Noth, Gottfried. 1930. Grundzuege Der Theologie Des Martin Chemnitz. Erlangen.

Olsen, Arthur L. 2000. The Hermeneutical Vision of Martin Chemnitz: The Role of Scripture and Tradition in the Teaching Church. In Bast, Robert J. et al (eds.). Continuity and change: the harvest of late medieval and Reformation history: essays presented to Heiko A. Oberman on his 70th birthday. Leiden; Boston: Brill, 314-332.

Pannenberg, Wolfhart. 1977. Jesus, God and Man. 2nd ed. Philadelphia.

Rusch, William G. 1987. Lutheran Teaching on Christology and its Implications for LutheranOrthodox Relations. In Fries, Paul - Nersoyan, Tiran (eds.). Christ in East and West. Macon, 129-146.

Stewart, Quentin D. 2015. Lutheran Patristic Catholicity. Vol. 20. Münster.

Tsirpanlis, Constantine N. 1982. The Historical and Ecumenical Significance of Jeremias II's Correspondence with the Lutherans (1573-1581). Kingston, NY.

Valčo, Michal. 2007. Scripture as a Source of Chemnitz' Christology. In Communications: Scientific Letters of the University of Zilina 9/2, 5-8.

Valčo, Michal. 2010. Sedes Doctrinae in the Eucharistic Christology of Martin Chemnitz. In Roczniki Teologiczno-pastoralne 5. Tarnów.

Volk, Ernst. 1987. Evangelical Accents in the Understanding of the Lord's Supper. In Lutheran Quarterly 1/2, 180-195.

Watson, J. Francis. 1994. Martin Chemnitz and the Eastern Church: A Christology of the Catholic Consensus of the Fathers. In Saint-Vladimir's-Theological-Quarterly 38/1, 73-86.

SUMMARY: CHEMNITZ'S EUCHARISTIC CHRISTOLOGY AS AN IMPULSE FOR ECUMENICAL DIALOGUE BETWEEN EAST AND WEST. Martin Chemnitz was an important second-generation, reformation theologian. His theological significance was coupled with his significance as a pastor and church administrator. To gain a clearer understanding of Chemnitz's Christology and his theology of the Eucharist, it is important to consider the formative events of his life, his ecclesiastical-political struggles, as well as his pastoral approach to matters, which he considered most important. Chemnitz combined Luther's theological insights and exegetical skills with Melanchthon's logical methods of argumentation in his patient search for concord. His major theological contribution, besides his important theological treatises (such as Loci Theologici, De duabus naturis, Examen Concilii Tridentini, etc.), was his development of an historical method, which he used in his polemics, thus delineating the roots and context of legitimate 'Gospel theology.' This method is comprised of: (1) Biblical exegesis, (2) thorough research of the church's tradition to guide exegesis (keeping the Scriptures as the ultimate authority in case of discrepancies or conflicting views), (3) dogmatic construction, and (4) apologetics. Chemnitz used this method in developing and using his Christological teaching in several key doctrines, including his doctrine of the Eucharist. Beside the norma normans (i.e. Scriptures), he extensively used the witness of the ancient fathers of the church - including Eastern church fathers, which distinguished him from other Protestant theologians of his time - as a legitimate source of Christology. Chemnitz relied on what he called a "catholic consensus of the fathers" with regard to the basic teachings of the gospel. This "catholic consensus," however, was but a further development of the tradition of biblical interpretation within the living organism - the ecumenical Body of Christ. This principal of biblical interpretation (seen critically in the context of the consensus of the fathers) can be discovered in Chemnitz's works on the Eucharist. The witness of biblical interpretation of the Christological passages as found in Cyril of Alexandria, John of Damascus, or Basil the Great is welded together with 
the words of institution, as found in the Gospels and in Paul, the apostle. This combined witness of Scriptures and tradition clearly shows, according to Chemnitz, that Christ's words of the institution (of the Eucharist) are meant to be taken literally and understood in their proper sense and context. Christology, though not a starting point in Chemnitz's exegesis of the sedes doctrinae of the doctrine of the Eucharist, has a very clear and definitive significance for this teaching. By means of a legitimate analogy between the hypostatic union of the two natures in Christ and union of Christ's body and blood with the elements of bread and wine in the Supper Chemnitz demonstrates not only the possibility (or feasibility) but also the necessity of the sacramental union. Chemnitz's approach carries a relevant ecumenical potential for the dialogue between Eastern and Western branches of Christianity, beginning with Christology and Sacramentology, and continuing down to theological hermeneutics (above all with respect to the relationship Scripture and tradition), Christian liturgy and ethics.

doc. PhDr. Michal Valčo, PhD.

Constantine the Philosopher University in Nitra

Faculty of Arts

Department of General and Applied Ethics

Hodžova 1

94974 Nitra

Slovakia

mvalco@ukf.sk 